\title{
EFEKTIVITAS BIOFILTER ANAEROB AEROB MEDIA BATA STYROFOAM SISTEM ALIRAN KE ATAS DALAM MENURUNKAN KADAR BOD, COD DAN COLIFORM PADA AIR LIMBAH RUMAH SAKIT PROF. Dr. V.L. RATUMBUYSANG MANADO
}

\author{
Arland Diadon ${ }^{1)}$, Tony K. Timpua ${ }^{2)}$, Anselmus Kabuhung ${ }^{3)}$ \\ ${ }^{1)}$ Dinas Kesehatan Kabupaten Maluku Utara \\ 2,3) Jurusan Kesehatan Lingkungan Poltekkes Kemenkes Manado \\ Email : arlan.diadon@gmail.com
}

\begin{abstract}
The most common obstacle found by hospitals is to make wastewater disposal installations, the existing technology is still quite expensive, while the funds available to build wastewater treatment equipment units are still limited because it needs to develop cheap hospital wastewater treatment technology, easy operation, using resources that are easily available and affordable. This research was carried out to make a prototype of device, anaerobic aerobic biofilter brick Styrofoam upward flow system, regulate discharge, adjust residence time, take samples and measure the levels of BOD, COD and Coliform. The aim of the study was to determine the effectiveness of biofilter in aerobic anaerobic brick Styrofoam Upstream system in reducing levels of BOD, COD, and coliform hospital wastewater, to determine the relationship of discharge and residence time to the effectiveness anaerobic biofilter of brick Styrofoam in reducing BOD, COD levels and Coliform hospital wastewater. This type of research is a quasi-experimental design with time series such as pre-test and post-test. Samples were taken before and after processing 30 samples. The results showed that aerobic anaerobic biofilter brick media was Styrofoam able to reduce BOD $85.25 \%-93.65 \%$, COD $87.79 \%-94.19 \%$ and coliform $85 \%-96.87 \%$. Statistical test results have significant differences and correlations of discharge and residence time to decreasing levels of BOD, COD and coliform hospital wastewater before and after processing with aerobic anaerobic biofilter brick Styrofoam upward flow system. Thus it can be concluded that aerobic anaerobic biofilter brick Styrofoam upflow system is effective in reducing the levels of BOD, COD and coliform with an average efficiency of $90 \%$.
\end{abstract}

Keywords : Aerobic Anaerobic Biofilter Brick StyrofoamUpward Flow System, Hospital Wastewater, BOD, CODLevels and Coliform

\begin{abstract}
Abstrak. Kendala paling banyak dijumpai oleh Rumah Sakit untuk membuat IPAL yakni teknologi yang ada saat ini masih cukup mahal, sedangkan dana yang tersedia untuk membangun unit alat pengolah air limbah tersebut masih terbatas karena itu perlu dikembangkan teknologi pengolahan air limbah rumah sakit yang murah, mudah operasinya, menggunakan sumber daya yang mudah di dapat serta harganya terjangkau. Penelitian ini dilakukan membuat prototip alat biofilter anaerob aerob media bata Styrofoam sistem aliran ke atas, mengatur debit, mengatur waktu tinggal, mengambil sampel dan mengukur kadar BOD, COD dan Coliform. Tujuan penelitian untuk mengetahui efektivitas biofilter anaerob aerob media bata Styrofoam sistem aliran ke atas dalam menurunkan kadar BOD, COD, dan coliform air limbah rumah sakit, untuk mengetahui hubungan debit dan waktu tinggal terhadap efektivitas biofilter anaerob aerob media bata Styrofoam dalam menurunkan kadar BOD, COD dan Coliform air limbah rumah sakit. Jenis penelitian ini adalah eksperimen semu dengan rancangan rangkaian waktu seperti pretest dan post-test. Sampel diambil sebelum dan sesudah pengolahan sebanyak 30 sampel. Hasil penelitian menunjukkan bahwa biofilter anaerob aerob media bata Styrofoam mampu menurunkan BOD 85,25 \% - 93,65\%, COD 87,79\% - 94,19\% dan coliform $85 \%$ - 96,87\%. Hasil uji statistik ada perbedaan dan korelasi yang signifikan debit dan waktu tinggal terhadap penurunan kadar BOD, COD dan coliform air limbah rumah sakit sebelum dan sesudah pengolahan dengan biofilter anaerob aerob media bata Styrofoam sistem aliran ke atas. Dengan demikian dapat disimpulkan bahwa biofilter anaerob aerob media bata Styrofoam sistem aliran keatas efektif menurunkan kadar BOD, COD dan coliform dengan efisiensi rata-rata $90 \%$.
\end{abstract}

Kata kunci : Biofilter Anaerob Aerob Media Bata Styrofoam Sistem Aliran Keatas, Air Limbah Rumah Sakit, Kadar BOD, COD dan Coliform

Rumah sakit bagian integral dari suatu organisasi sosial dan kesehatan dengan fungsi menyediakan pelayanan paripurna (komprehensif), penyembuhan penyakit (kuratif) dan pencegahan penyakit (preventif) kepada masyarakat. Tugas rumah sakit umumnya adalah melaksanakan upaya pelayanan kesehatan secara berdaya guna dan berhasil guna dengan mengutamakan penyembuhan dan pemulihan yang dilaksanakan secara serasi dan terpadu dengan peningkatan dan pencegahan serta pelaksanaan upaya rujukan dimana untuk menyelenggarakan fungsinya, maka Rumah Sakit menyelenggarakan kegiatan pelayanan medis, pelayanan dan asuhan 
keperawatan, pelayanan penunjang medis dan nonmedis, pelayanan kesehatan kemasyarakatan dan rujukan, pendidikan, penelitian dan pengembangan, Administrasi umum dan keuangan (UU No. 44 tahun 2009).

Air limbah rumah sakit yang berasal dari buangan domistik maupun buangan limbah cair klinis umumnya mengadung senyawa pulutan organik yang cukup tinggi, dan dapat diolah dengan proses pengolahan secara biologis, sedangkan untuk air limbah rumah sakit yang berasal dari laboratorium biasanya banyak mengandung logam berat yang mana bila air limbah tersebut dialirkan ke dalam proses pengolahan secara biologis, logam berat tersebut dapat mengganggu proses pengolahannya. Maka air limbah yang berasal dari laboratorium dipisahkan dan ditampung, kemudian diolah secara kimia-fisika (Kristanto, 2002)

Hasil penelitian yang dilakukan oleh Timpua (2005) menunjukan bahwa Tricling Filter Up Flow dapat menurunkan kadar limbah cair dengan efisiensi berturut-turut BOD antara $89.20 \%-93.72 \%$, COD antara $85.96 \%-94.67 \%$ dan E.Coli antara 62.94\% - 90.66\%

Biofilter Anaerob Aerob Media Bata Styrofoam Sistem Aliran Keatas terdiri dari beberapa bagian yakni bak pengendapan awal, bak anaerob, bak aerob dan bak pengendapan akhir bertujuan untuk menghilangkan bahanbahan organik dan menurunkan BOD, COD, dan Coliform dengan menggunakan bantuan mikroorganisme seperti fungi, virus, bakteri yang ada dalam air limbah apabila berlangsung baik pengolahan tersebut mampu menurunkan BOD, COD dan Coliform sehingga air hasil olahan telah memenuhi persyaratan standar yang berlaku (Sunu, 2001)

Tujuan penelitian untuk mengetahui Efektivitas Biofilter Anaerob Aerob Media Bata Styrofoam Sistem Aliran Keatas dalam menurunkan BOD, COD dan Coliform air limbah rumah sakit Prof. Dr. V.L. Ratumbuysang Manado, mengetahui hubungan Debit air limbah terhadap Efektivitas Biofilter Anaerob Aerob Media Bata Styrofoam Sistem Aliran Keatas dalam menurunkan kadar BOD, COD dan Coliform air limbah rumah sakit Prof. Dr. V.L. Ratumbuysang Manado, mengetahui hubungan waktu tinggal air limbah terhadap Efektivitas Biofilter Anaerob Aerob Media Bata
Styrofoam Sistem Aliran Keatas dalam menurunkan kadar BOD, COD dan Coliform air limbah rumah sakit Prof. Dr. V.L. Ratumbuysang Manado, mengetahui hubungan suhu terhadap Efektivitas Biofilter Anaerob Aerob Media Bata Styrofoam Sistem Aliran Keatas dalam menurunkan kadar BOD, COD dan Coliform air limbah rumah sakit Prof. Dr. V.L. Ratumbuysang Manado, mengetahui hubungan $\mathrm{pH}$ terhadap Efektivitas Biofilter Anaerob Aerob Media Bata Styrofoam Sistem Aliran Keatas dalam menurunkan kadar BOD, COD dan Coliform air limbah rumah sakit Prof. Dr. V.L. Ratumbuysang Manado.

\section{Metode}

Jenis penelitian ini adalah penelitan experiment. Penelitian eksperimen atau percobaan (experimental research) adalah penelitian dengan melakukan kegiatan percobaan (research) yang bertujuan untuk mengetahui gejala atau pengaruh yang timbul sebagai akibat dari adanya perlakuan tertentu. Percobaan ini berupa perlakuan atau intervensi terhadap suatu variabel. Variabel kontrol dalam penelitian ini adalah debit aliran, waktu tinggal, suhu dan $\mathrm{pH}$, mempunyai keuntungan dengan melakukan pengukuran yang berulang-ulang sebelum dan sesudah perlakuan yang dapat digunakan sebagai berikut

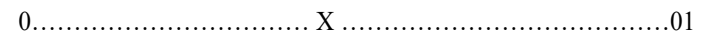

Keterangan :

0 : Kadar BOD, COD, dan Coliform Air Limbah Rumah Sakit sebelum pengolahan.

01 : Kadar BOD, COD dan Coliform air limbah Rumah Sakit sesudah pengolahan.

X : Pengolahan air limbah Rumah sakit dengan Biofilter Anaerob Aerob Media Bata Styrofoam Sistem Aliran Ke Atas.

Variabel Penelitian

1. Variabel bebas yaitu kadar BOD, COD, dan Coliform sebelum pengolahan.

2. Variabel Terikat yaitu Biofilter Aerob Anaerob Media Bata Styrofoam Sistem Aliran Keatas, Kadar BOD, COD dan Coliform sesudah pengolahan.

3. Variabel kontrol yaitu Debit Air Limbah, Waktu tinggal air limbah, Suhu dan $\mathrm{pH}$. 
Untuk mengetahui ada tidaknya pengaruh / hubungan antara variable $\mathrm{X}$ dan variable $\mathrm{Y}$ maka dapat dijelaskan sebagai berikut :

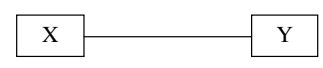

Keterangan :

$\mathrm{X}$ : Kadar BOD, COD dan Coliform sebelum pengolahan (treatment)

Y : Efektivitas Biofilter Anaerob Aerob Media Bata Styrofoam Sistem Aliran Keatas dengan indikator kadar BOD, COD dan Coliform sesudah pengolahan (treatment.

Populasi dalam penelitian ini adalah semua air limbah yang dihasilkan oleh Rumah Sakit yang sudah dialirkan melalui instalasi pengolahan limbah kemudian diambil untuk diolah dengan Biofilter Anaerob Aerob Media Bata Styrofoam Sistem Aliran Keatas. Sampel adalah sebagian dari limbah cair yang diambil dari bak equalisasi sehingga diperoleh karakteritik limbah yang homogen. Penanganan sampel dilakukan dengan cara sebagai berikut : Pengambilan di Rumah Sakit, wadah sampel berupa jergen plastik volume 25 liter dimasukan kedalam bak equalisasi melalui lubang kontrol, dan untuk menghindari oksidasi, mulut jergen diletakkan di bawah permukaan air limbah kemudian diisi hingga penuh guna menghindari terjadinya guncangan pada saat pengangkutan. Volume air limbah yang diangkut setiap hari adalah 600 liter., Pengangkutan sampel : sampel diangkut dengan mobil tertutup pada waktu malam hari untuk menghindari kontak dengan sinar matahari yang berlebihan karena hal ini akan mempengaruhi suhu air limbah dalam wadah, Pengisian Biofilter : air limbah Rumah Sakit di masukkan melalui bak equalisasi kemudian dialirkan secara terus menerus pada biofilter dengan mengatur kapasitas aliran secara bervariasi yaitu : $0,3 \mathrm{l} / \mathrm{menit}, 0,51 /$ menit, 0,7 1/menit, $0,9 \quad 1 /$ menit dan 1 liter/menit, Pengambilan sampel pada biofilter : metode sampling yang digunakan pada penelitian ini adalah sampel sesaat (grap sample) yaitu sampel diambil langsung dari kran biofilter pada saat tertentu. Sampel diambil setiap hari sebelum dan sesudah pengolahan. Sebelum pengolahan, diambil pada bak aqualisasi melalui kran pengambil sampel selanjutnya diberi kode A1, sedangkan sesudah pengolahan diambil pada pipa pengeluaran akhir dan diberi kode B1. Wadah sampel menggunakan botol winkler volume $250 \mathrm{ml}$ untuk analisa BOD dan COD sedangkan pengambilan sampel secara bakteriologi menggunakan botol yang sudah disterilkan. Instrumen yang digunakan dalam penelitian :

1. Sebagai instrument dalam penelitian ini adalah :

a. Bofilter Anaerob Aerob Media Bata Styrofoam Sistem Aliran Keatas

b. Inkubator

c. Air limbah rumah sakit

d. Alat untuk mengukur atau menghitung jumlah bakteri dengan metode tabung ganda.

e. Do meter

f. Thermometer

g. $\mathrm{pH}$ meter

h. Alat untuk mengukur debit menggunakan literan.

Data hasil penelitian ini di analisis dalam bentuk tabel, grafik dinarasikan dalam statistik menggunakan uji-t dan regresi, pengolahan data dengan SPSS 20.

\section{Hasil}

Berdasarkan hasil uji laboratorium Balai Teknik Kesehatan Lingkungan dan Pengendalian Penyakit Kelas I Manado bahwa hasil pengolahan biofilter dapat dijelaskan sebagai berikut :

1. Biological Oxygen Deman (BOD) Berdasarkan hasil pemeriksaan kadar BOD dengan sampel $300 \mathrm{ml}$. Kapasitas aliran dan waktu detensi yang bervariasi diketahui biofilter anaerob dan aerob media bata. Styrofoam menunjukkan kemampuan (efisiensi) menurunkan kadar BOD air limbah rumah sakit antara $85.25 \%$ sampai 93,65\%. Kadar BOD sebelum dan sesudah pengolahan dengan biofilter anaerob dan aerob media bata styrofoam Aliran dari bawah ke atas dapat dilihat pada tabel 1 berikut : 
Tabel 1. Kadar BOD Sebelum dan Sesudah Pengolahan dengan Biofilter Anaerob Aerob Media Bata Styrofoam Sistem Aliran Keatas

\begin{tabular}{|c|c|c|c|c|c|}
\hline \multirow{2}{*}{$\begin{array}{l}\text { Debit } \\
\text { (1/Jam) }\end{array}$} & \multirow{2}{*}{$\begin{array}{c}\text { Waktu } \\
\text { Tinggal (Jam) }\end{array}$} & \multicolumn{2}{|c|}{ BOD $(\mathrm{mg} / \mathrm{l})$} & \multirow{2}{*}{$\begin{array}{c}\text { Selisih } \\
\text { Penurunan } \\
\text { (mg) }\end{array}$} & \multirow{2}{*}{$\begin{array}{c}\text { Penurunan } \\
(\%)\end{array}$} \\
\hline & & Sebelum & Sesudah & & \\
\hline 18 & 18 & 164,32 & 10,43 & 153,89 & 93,65 \\
\hline 30 & 11 & 172,47 & 12,83 & 159,64 & 92,56 \\
\hline 42 & 8 & 183,61 & 12,33 & 171.28 & 93,28 \\
\hline 54 & 6 & 188,52 & 26,03 & 162,49 & 86,19 \\
\hline 60 & 5 & 186,73 & 27,53 & 159,2 & 85.25 \\
\hline \multicolumn{2}{|c|}{ Rata-rata } & 179,13 & 17,83 & 161,3 & 90.186 \\
\hline
\end{tabular}

Berdasarkan tabel 1 dapat dijelaskan bahwa persentase penurunan kadar BOD tertinggi terjadi pada debit aliran $18 \mathrm{l} / \mathrm{jam}$ dengan waktu tinggal 18 jam yaitu $93,65 \%$ dan terendah pada debit aliran 60 1/jam dengan waktu tinggal 5 jam yaitu $84,37 \%$

2. Chemical Oxygen Demand (COD)

Berdasarkan hasil pemeriksaan kadar COD dengan sampel $300 \mathrm{ml}$. Kapasitas aliran dan waktu detensi yang bervariasi diketahui biofilter anaerob dan aerob media bata styrofoam menunjukkan kemampuan (efisiensi ) menurunkan kadar COD air limbah rumah sakit antara $87.79 \%$ sampai 94.19\%. Rerata kadar COD sebelum dan sesudah pengolahan dengan Biofilter Anaerob Aerob Media Bata Styrofoam Aliran keatas dapat dilihat pada tabel 2 berikut :

Tabel 2. Kadar COD Sebelum dan Sesudah Pengolahan dengan Biofilter Anaerob Aerob Media Bata Styrofoam Sistem Alira Ke Atas

\begin{tabular}{|c|c|c|c|c|c|}
\hline \multirow{2}{*}{$\begin{array}{c}\text { Debit } \\
\text { (1/Jam) }\end{array}$} & \multirow{2}{*}{$\begin{array}{l}\text { Waktu Tinggal } \\
\text { (Jam) }\end{array}$} & \multicolumn{2}{|c|}{ COD $(\mathrm{mg} / 1)$} & \multirow{2}{*}{$\begin{array}{c}\text { Selisih } \\
\text { Penurunan } \\
\text { (mg) }\end{array}$} & \multirow{2}{*}{$\begin{array}{c}\text { Penurunan } \\
(\%)\end{array}$} \\
\hline & & Sebelum & Sesudah & & \\
\hline 18 & 18 & 503.48 & 45 & 458.48 & 91,06 \\
\hline 30 & 11 & 499.65 & 61 & 438.65 & 87.79 \\
\hline 42 & 8 & 537.12 & 46 & 491.12 & 91.43 \\
\hline 54 & 6 & 562 & 43 & 519 & 92,34 \\
\hline 60 & 5 & 516.42 & 30 & 486.42 & 94.19 \\
\hline \multicolumn{2}{|c|}{ Rata-rata } & 523,734 & 45 & 478,734 & 91,362 \\
\hline
\end{tabular}

Berdasarkan tabel 2 dapat dijelaskan bahwa persentase penurunan kadar COD tertinggi terjadi pada debit 60 1/jam yaitu $94.19 \%$ dengan waktu tinggal 5 jam dan terendah pada debit 30 1/jam dengan waktu tinggal 11 jam yaitu 87.79 $\%$

3. Coliform

Berdasarkan hasil pemeriksaan MPNColiform dengan sampel $300 \mathrm{ml}$. Kapasitas aliran dan waktu detensi yang bervariasi diketahui Biofilter Anaerob dan Aerob Media Bata Styrofoam menunjukkan kemampuan (efisiensi) menurunkan Coliform air limbah rumah sakit antara $85 \%$ sampai $96.87 \%$. MPN-Coliform sebelum dan sesudah pengolahan dengan Biofilter Anaerob Aerob Media Bata Styrofoam Aliran dari bawah keatas dapat dilihat pada tabel 1 berikut :

Tabel 3. MPN Coliform sebelum dan sesudah Pengolahan dengan Biofilter Anaerob Aerob Media Bata Styrofoam Aliran Ke Atas

\begin{tabular}{|c|c|c|c|c|c|}
\hline \multirow{2}{*}{$\begin{array}{l}\text { Debit } \\
\text { (1/Jam) }\end{array}$} & \multirow{2}{*}{$\begin{array}{c}\text { Waktu } \\
\text { Tinggal (Jam) }\end{array}$} & \multicolumn{2}{|c|}{ MPN Coliform } & \multirow{2}{*}{$\begin{array}{c}\text { Selisih } \\
\text { Penurunan } \\
\text { (Koloni) }\end{array}$} & \multirow{2}{*}{$\begin{array}{c}\text { Penurunan } \\
(\%)\end{array}$} \\
\hline & & Sebelum & Sesudah & & \\
\hline 18 & 18 & $>16000$ & 500 & 15500 & 96.87 \\
\hline 30 & 11 & $>16000$ & 900 & 15100 & 94.37 \\
\hline 42 & 8 & $>16000$ & 1200 & 14800 & 92.5 \\
\hline 54 & 6 & $>16000$ & 2400 & 13600 & 85 \\
\hline 60 & 5 & $>16000$ & 2400 & 13600 & 85 \\
\hline \multicolumn{2}{|c|}{ Rata-rata } & $>16000$ & 1480 & 14520 & 90,748 \\
\hline
\end{tabular}


Berdasarkan tabel 3 dapat dijelaskan bahwa penurunan MPN Coliform tertinggi terjadi pada debit aliran 18 l/jam dengan waktu tinggal 18 jam yaitu $96.87 \%$ dan terendah pada debit aliran 60 1/jam dengan waktu tinggal 5 jam serta debit 54 1/jam dengan waktu tinggal 6 jam yaitu $85 \%$.

\section{Pembahasan}

1. Biological Oxygen Demand (BOD)

Hasil penelitian menunjukkan bahwa jika dibandingkan dengan kadar BOD sebelum dan sesudah pengolahan ternyata kadar BOD pada debit 18 1/jam dengan waktu tinggal 18 jam relatif lebih tinggi yaitu 93,28 \%. Hal ini disebabkan karena kadar BOD sebelum pengolahan relatif lebih tinggi dan waktu tinggal air limbah yang lambat sehingga proses dekomposisi bahan organik lebih optimal karena tersedia cukup nutrisi yang memungkinkan perkembangbiakan bakteri lebih cepat. Pada debit 60 1/jam dengan waktu tinggal 5 jam penurunan BOD relatif kecil yaitu $84,37 \%$, hal ini disebabkan karena kadar BOD sebelum pengolahan cukup tinggi yang memungkinkan kebutuhan nutrisi oleh bakteri terpenuhi akan tetapi waktu tinggal air limbah terlalu cepat sehingga proses dekomposisi bahan organik tidak optimal, dengan demikian dapat dikatakan bahwa pengolahan dengan Biofiter Anaerob dan Aerob Media Bata Styrofoam Sistem Aliran Ke Atas efektif menurunkan kadar BOD. Untuk memperjelas hubungan antara debit aliran dan waktu tinggal terhadap efisiensi Biofilter Anaerob Aerob Media Bata Styrofoam Sistem Aliran Ke Atas dalam menurunkan kadar BOD dapat dilihat pada gambar 1 dibawah ini :

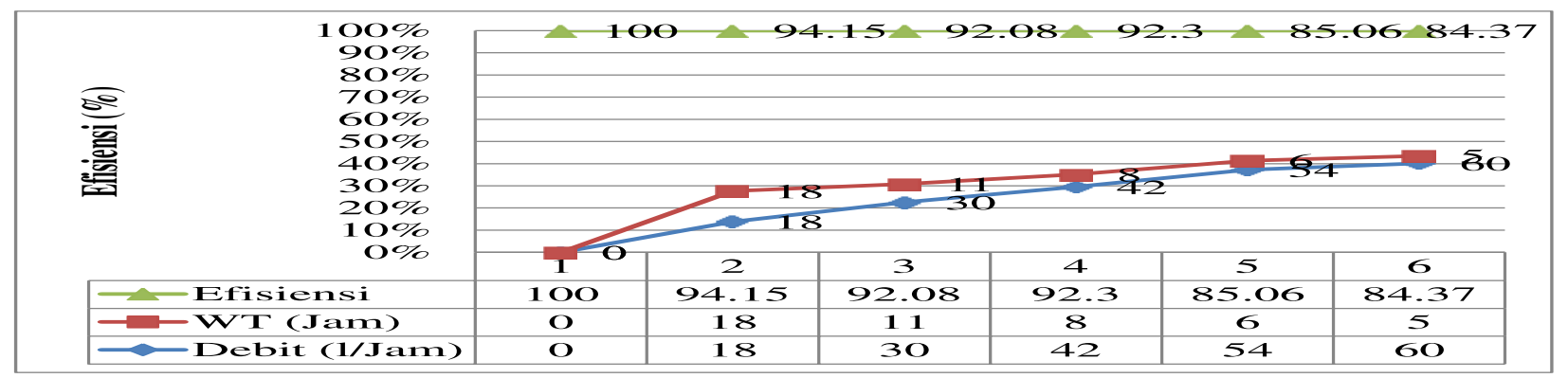

Gambar 1. Hubungan Debit Aliran dan Waktu Tinggal dengan Efisiensi Biofilter.

Berdasarkan gambar 1, secara keseluruhan pengolahan dengan Biofilter Anaerob Aerob Media Bata Styrofoam Sistem Aliran Ke Atas telah mampu menurunkan kadar BOD lebih kecil dari baku mutu air limbah yaitu $30 \mathrm{mg} / \mathrm{l}$ (Kep58/MENLH/12/1995 tentang Baku Mutu Limbah Cair Bagi Kegiatan Rumah Sakit). Untuk mengetahui hubungan antara debit aliran dan waktu tinggal terhadap perbedaan kadar BOD sebelum dan sesudah pengolahan dengan Biofilter Anaerob Aerob Media Bata Styrofoam Sistem Aliran Ke Atas dapat dilihat pada gambar 2 dibawah ini :

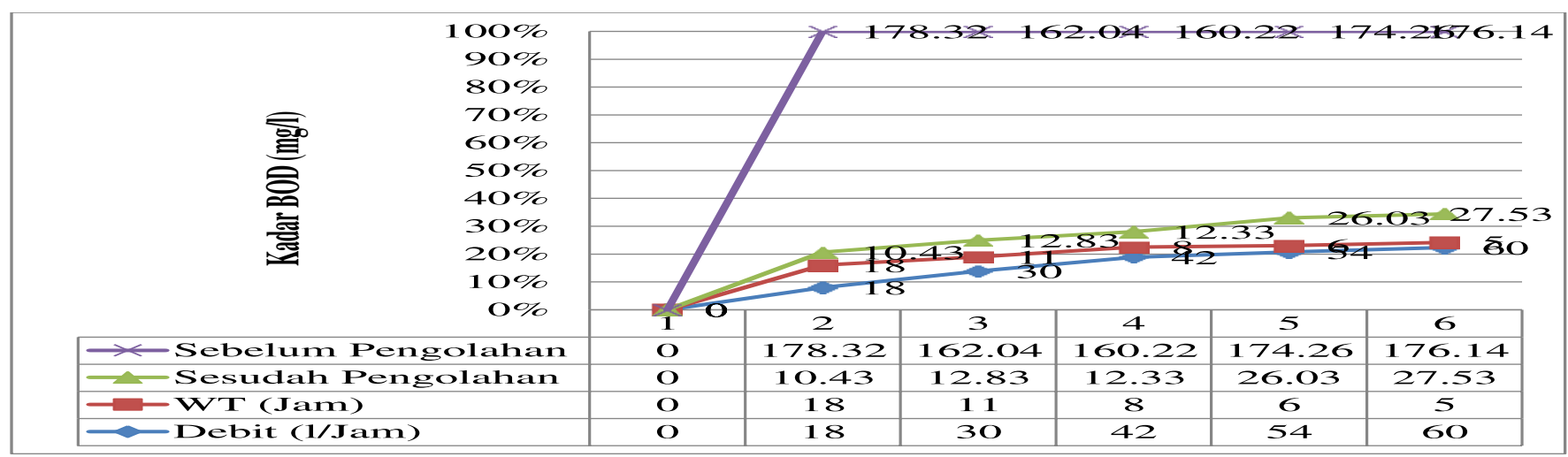

Gambar 2. Mubungan Debit Aliran dan Waktu Tinggal dengan Perbedaan Kadar BOD Air Limbah Rumah Sakit Sebelum dan Sesudah Pengolahan. 
Proses penurun BOD pada Biofilter Anaerob Aerob Media Bata Styrofoam Sistem Aliran Ke Atas tersebut sudah dimulai sejak air limbah berada dalam bak equalisasi karena adanya pengendapan partikel-partikel zat organik tersuspensi tidak stabil dan yang relatif besar secara grafitasi di dasar bak. Adanya pengendapan partikel zat organik ini diketahui dengan adanya endapan lumpur didasar bak equalisasi. Mengendapnya sebagian zat organik, menyebabkan kebutuhan oksigen untuk mendegradasi zat organik secara biologis oleh mikrobia berkurang sehingga kemampuan biodegradasi di dalam air limbah oleh mikrobia akan menurun (Sugiyono, 2011)

Selanjutnya penurunan kadar BOD terjadi pada biofilter anaerob dimana pada situasi mikroba anaerob yang tumbuh pada media bata Styrofoam berperan sebagai pengurai zat organik di dalam air limbah saat melewati biofilter anaerob. Saat masuk kedalam biofilter anaerob mikroorganisme aerob masih hidup karena kandungan oksigen dalam air limbah masih ada, tetapi kemudian mati karena kehabisan oksigen.

Penurunan BOD selanjutnya terjadi pada biofilter aerob. Beban pengolahan pada proses aerob lebih rendah sehingga prosesnya ditempatkan sesudah proses anaerob. Sistem ini memiliki organisme yang menempel pada bata Styrofoam dan mengolah air melalui kontak dengan air limbah yang biasanya sering disebut metode biofilm. Mekanisme pembentukan biofilm dimulai ketika sel melekat pada kepermukaan sel lainnya dan melakukan gerak acak untuk mencari penyesuaian lingkungan dengan permukaan media dan selanjutnya melekat erat pada permukaan media. Pada biofilter aerob ada penambahan oksigen sebagai aerasi dengan menghembuskan udara kedalam biofilter aerob yang melewati media sehingga mikroorganisme yang ada akan menguraikan zat organik yang ada dalam air limbah serta tumbuh dan menempel pada permukaan media. Dengan demikian air limbah akan kontak dengan mikroorganisme yang tersuspensi dalam air maupun yang menempel pada permukaan media yang mana hal tersebut dapat meningkatkan efisiensi penguraian zat organik, deterjen dan mempercepat proses nitrifikasi, sehingga efisiensi penghilangan amoniak menjadi lebih besar. Disamping itu lamanya waktu tinggal dan lambatnya aliran air limbah didalam biofilter anaerob aerob media bata Styrofoam memberi kesempatan partikel zat organik tersuspensi yang relatif besar mengendap, dengan pengendapan tersebut kadar BOD turun karena jumlah zat organik yang harus didegradasi dan mikroorganisme dalam air limbah berkurang.

Pengolahan dengan biofilter anaerob aerob media bata Styrofoam sistem aliran keatas mampu menurunkan kadar BOD antara 84,37\% 93,65\% yang berarti bahwa kemampuan (efisiensi) biofilter anaerob aerob media bata Styrofoam dalam menurunkan kadar BOD tergolong baik. Hasil temuan ini lebih tinggi dari temuan Sigit (2002) dengan modifikasi septic tank dapat menurunkan BOD sebesar 235-775, tetapi relatif lebih rendah dibandingkan dengan temuan Timpua (2005) yang menggunakan Trickling Filter Up Flow mampu menurunkan BOD antara $89,20 \%-93,72 \%$.

Berdasarkan tabel 1 dapat diketahui bahwa dengan debit air limbah dan waktu tinggal yang bervariasi, rata-rata persentase penurunan kadar BOD sebelum dan sesudah pengolahan dengan biofilter anaerob aerob media bata Styrofoam sistem aliran keatas mencapai $90 \%$ hal ini berarti bahwa biofilter anaerob aerob media bata Styrofoam sistem aliran keatas efektif dalam menurunkan kadar BOD air limbah rumah sakit. Untuk mengetahui apakah terdapat perbedaan yang signifikan kemampuan biofilter anaerob aerob media bata Styrofoam sistem aliran keatas sebelum dan sesudah pengolahan maka dilakukan uji statistik sebagai berikut : 
Tabel 4. Hasil Uji Statistik Pengaruh Perbedaan Debit dan Waktu Tinggal terhadap Efisiensi biofilter

\begin{tabular}{clccc}
\hline No & \multicolumn{1}{c}{ Tes } & $\begin{array}{c}\text { Jenis } \\
\text { Uji }\end{array}$ & Signifikansi & Kesimpulan \\
\hline 1 & Efektifitas Biofilter & T-Test & O,OOO & Signifikan \\
2 & $\begin{array}{l}\text { Hubungan Debit dengan } \\
\text { Efektifitas Biofilter }\end{array}$ & Regresi & O,018 & Signifikan \\
3 & $\begin{array}{l}\text { Hubungan Waktu Tinggal dengan } \\
\text { Efektifitas Biofilter }\end{array}$ & Regresi & O,O59 & Signifikan \\
\hline
\end{tabular}

Berdasarkan tabel 4 terlihat bahwa ada perbedaan penurunan kadar BOD sebelum dan sesudah pengolahan dengan demikian biofilter anaerob aerob media bata Styrofoam sistem aliran keatas efektif dalam menurunkan kadar BOD. Sedangkan untuk mengetahui hubungan variabel debit dengan penurunan BOD digunakan uji regresi. Hasil uji regresi diketahui korelasi debit (X1) dengan biofilter anaerob aerob media bata Styrofoam sistem aliran keatas (Y) $\mathrm{r}=0,902$ artinya terdapat hubungan yang positif antara variabel $\mathrm{X} 1$ dan $\mathrm{Y}$ dengan nilai signifikansi $<\alpha(0,018<0,05)$. Koefisien korelasi waktu tinggal (X2) dan biofilter anaerob aerob media bata Styrofoam sistem aliran keatas (Y) dengan nilai signifikansi $<\alpha(0,059<0,05)$ yang berarti hubungan antara (X1), (X2) dan (Y) signifikan. Nilai Koefisien korelasi $\mathrm{R}=0,949$ artinya besarnya hubungan antara debit (X1) dan waktu tinggal (X2) dan penurunan kadar BOD (Y) sebesar 94,9\% sedangkan nilai koefisien determinasi $\mathrm{R}=0,902$, yang berarti besarnya hubungan antara variabel debit (X1), waktu tinggal (X2) dan penurunan kadar BOD (Y) 90,2
\% ditentukan oleh variabel $\mathrm{X} 1$ dan $\mathrm{X} 2$ dan sisanya dipengaruhi oleh variabel lain (eror).

2. Chemical Oxygen Demand (COD)

Chemical Oxygen Demand (COD) adalah banyaknya oksigen yang dibutuhkan untuk mengoksidasi senyawa organik dalam air, sehingga parameter COD mencerminkan banyaknya senyawa organik yang dioksidasi secara kimia. Persentasi COD terendah pada debit 30 1/jam dan waktu tinggal 11 jam yaitu $87,79 \%$ sedangkan penurunan tertinggi pada debit 60 l/jam dan waktu tinggal 5 jam yaitu $94.19 \%$. Penurunan kadar COD rendah karena kadar BOD sebelum pengolahan rendah sehingga mempengaruhi proses oksidasi zat organik tidak optimal. Dengan demikian biofilter anaerob aerob media bata Styrofoam sistem aliran keatas efektif dalam menurunkan kadar COD. Untuk mengetahui hubungan debit dan waktu tinggal terhadap efisiensi biofilter anaerob aerob media bata styrofoam sistem aliran ke atas dalam menurunkan kadar COD dapat dilihat pada gambar 3 dibawah ini :

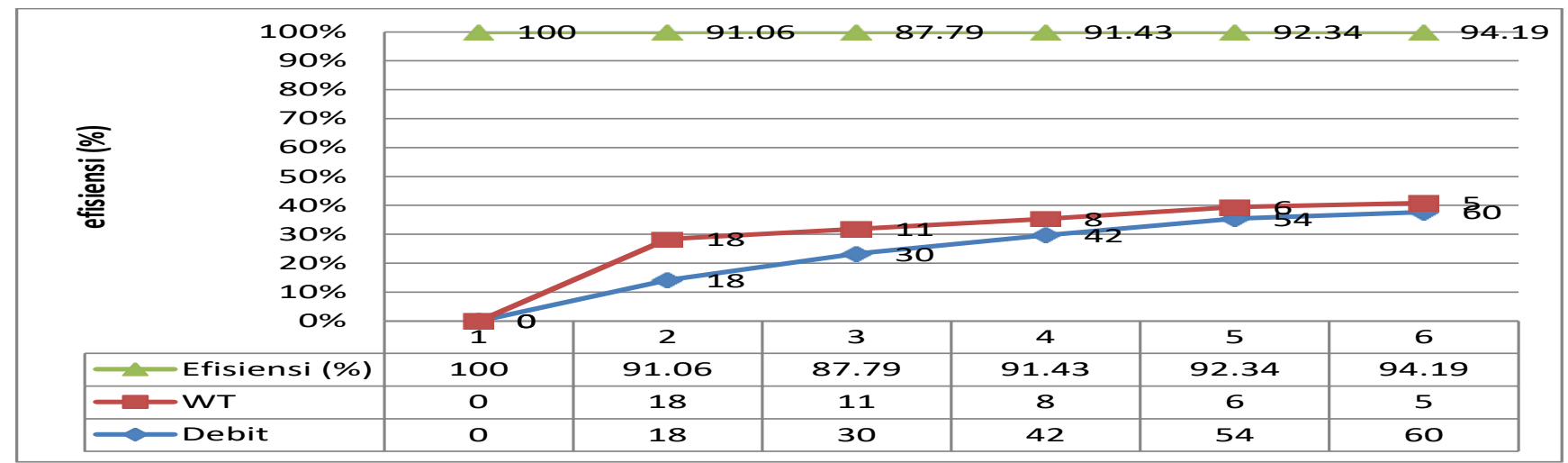

Gambar 3. Hubungan Debit Aliran dan Waktu Tinggal dengan Efisiensi Biofilter

Pada tabel 2 dan gambar 3 dapat dilihat bahwa setelah air limbah dialirkan ke dalam biofilter anaerob aerob media bata Styrofoam sistem aliran keatas mampu menurunkan kadar COD berkisar antara 87,79\% - 94,19\%. Hal ini menunjukan bahwa kadar COD mengalami penurunan. Penurunan kadar COD dalam air limbah dimulai sejak air limbah dimasukkan ke bak equalisasi karena terjadi pengendapan partikel-partikel zat organik tersuspensi. Hai ini 
dibuktikan dengan adanya endapan lumpur di dasar bak. Untuk mengetahui hubungan antara debit dan waktu tinggal terhadap perbedaan kadar COD sebelum dan sesudah pengolahan

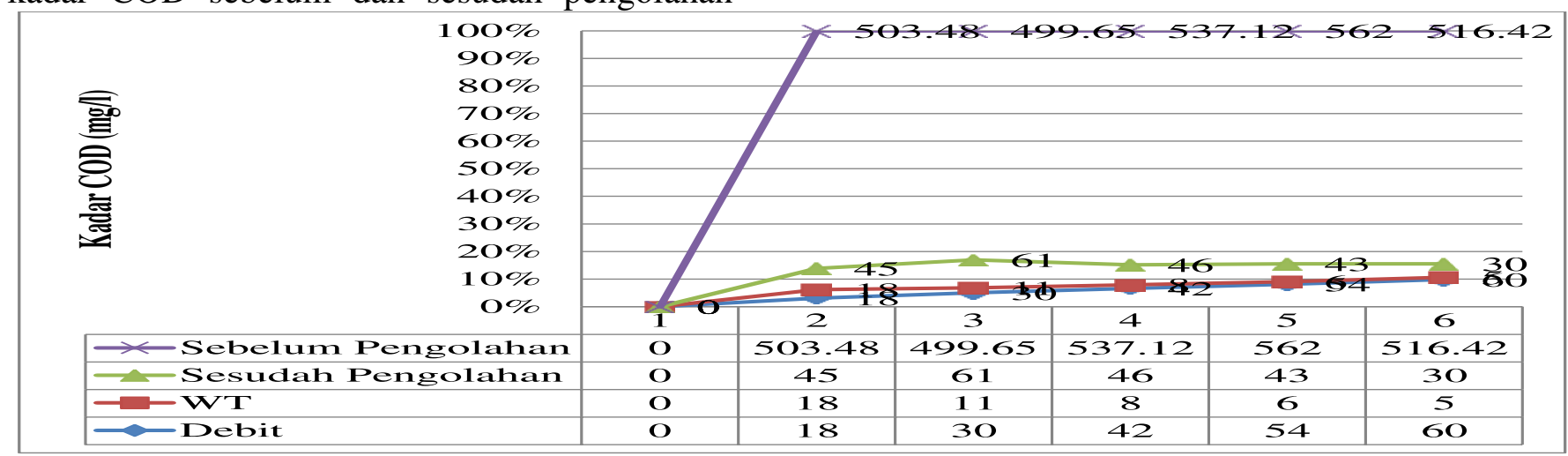

Gambar 4. Mubungan Debit dan Waktu Tinggal terhadap Perbedaan kadar COD.

Berdasarkan gambar 4 terlihat bahwa terdapat penurunan kadar COD. Proses penurunan kadar COD mulai sejak air limbah berada dalam bak equalisasi karena adanya pengendapan partikel-partikel zat organik tersuspensi, tidak stabil dan related besar secara grafitasi di dasar bak. Adanya pengendapan tersebut mengakibatkan kebutuhan oksigen untuk oksidasi zat organik berkurang.

Penurunan kadar COD selanjutnya terjadi pada biofilter anaerob dan biofilter aerob. Hal ini dengan biofilter anaerob aerob media bata Styrofoam dapat dilihat pada gambar 4 dibawah ini :

Tabel 5. Hasil Uji Statistik Pengaruh Perbedaan Debit dan Waktu Tinggal terhadap Efisiensi Biofilter Anaerob

\begin{tabular}{clccc}
\hline No & \multicolumn{1}{c}{ Tes } & $\begin{array}{c}\text { Jenis } \\
\text { Uji }\end{array}$ & Signifikansi & Kesimpulan \\
\hline 1 & Efektifitas Biofilter & T-Test & 0,000 & $\begin{array}{c}\text { Signifikan } \\
\text { Tidak } \\
2\end{array}$ \\
$\begin{array}{l}\text { Hubungan Debit dengan } \\
\text { Efektifitas Biofilter }\end{array}$ & Regresi & 0,122 & $\begin{array}{c}\text { Signifikan } \\
\text { Tidak }\end{array}$ \\
3 & $\begin{array}{l}\text { Hubungan Waktu Tinggal dengan } \\
\text { Efektifitas Biofilter }\end{array}$ & Regresi & 0,240 & Signifikan \\
\hline
\end{tabular}

Berdasarkan tabel 5 dapat dijelaskan bahwa dengan menggunakan uji T-test ada perbedaan penurunan kadar COD sebelum dan sesudah pengolahan. Untuk mengetahui besarnya hubungan antara variabel debit (X1) dengan Penurunan COD (Y) dilakukan uji regresi. Dari uji regresi diketahui korelasi $\mathrm{X} 1-\mathrm{Y}, \mathrm{r}=-0,642$ artinya terdapat hubungan berlawanan antara variabel X1 dan Y dimana semakin cepat debit aliran tidak diikuti dengan penurunan COD dengan nilai signifikansi $>\alpha(0,122>0,05)$ artinya hubungan tersebut tidak signifikan. Koefisien korelasi $\mathrm{X} 2-\mathrm{Y}=0,421$ yang berarti disebabkan oleh proses oksidasi bahan organik terjadi dengan hadirnya katalisator kalium bikromat menjadi gas $\mathrm{CO} 2$ dan $\mathrm{H} 2 \mathrm{O}$ sehingga kadar zat organik didalam air limbah mengalami penurunan. Untuk mengetahui apakah terdapat perbedaan bermakna kemampuan biofilter anaerob aerob media bata styrofoam sistem aliran keatas dalam menurunkan kadar COD, maka dilakukan uji statistik sperti pada tabel dibawah ini :

terdapat hubungan positif antara variabel X2 dan Y dengan nilai signifikansi $>\alpha(0,240>0,05)$ artinya hubungan tersebut tidak signifikan. Nilai koefisien korelasi $\mathrm{R}=0,939$ menunjukan bahwa besarnya hubungan antara debit (X1) dan waktu tinggal (X2) dan penurunan kadar COD (Y) sebesar 93,9\%. Sedangkan nilai koefisien determinasi $\mathrm{R}=0,882$, yang berarti besarnya hubungan antara variabel debit (X1) dan waktu tinggal (X2) dengan penurunan kadar COD (Y) $88,2 \%$ ditentukan oleh variabel $\mathrm{X} 1$ dan $\mathrm{X} 2$ dan sisanya dipengaruhi oleh variabel lain (eror).

3. MPN Coliform 
Setiap badan air tidak terlepas dari adanya bakteri pathogen yang berasal dari kotoran manusia maupun kotoran hewan dan dari tanah. MPN Coliform merupakan ukuran banyaknya jumlah coliform total didalam air limbah. Jumlah organisme coliform cukup banyak dalam usus manusia. Sekitar 200-400 miliar organisme ini dikeluarkan melalui tinja setiap harinya. Karena jarang sekali ditemukan dalam air, keberadaan bakteri ini dalam air memberi bukti kuat adanya kontaminasi tinja manusia.

Hasil penelitian pada tabel 3 menunjukan bahwa tidak terdapat perbedaan antara debit dan waktu tinggal terhadap persentase penurunan MPN coliform air limbah rumah sakit sebelum dan sesudah pengolahan. Akan tetapi terdapat kecenderungan bahwa semakin cepat debit aliran dan semakin cepat waktu tingga semakin kecil persentase penurunan coliform sebaliknya semakin lambat debit aliran dan semakin lama waktu tinggal semakin besar persentase penurunan coliform yang berarti bahwa biofilter anaerob aerob media bata Styrofoam efektif menurunkan coliform pada debit aliran yang lebih kecil dan waktu tinggal yang lebih lama. MPN coliform sesudah pengolahan lebih kecil dari baku mutu air limbah rumah sakit yaitu 10.000/100 $\mathrm{ml}$ air limbah (KEP58/MENLH/12/1995 tentang Baku Mutu Limbah Cair Bagi Kegiatan Rumah Sakit). Berdasarkan tabel 3 dapat digambarkan bahwa secara keseluruhan pengolahan air limbah rumah sakit dengan menggunakan Biofilter Anaerob Aerob Media Bata Styrofoam Sistem Aliran Ke Atas dapat menurunkan coliform. Untuk memperjelas hubungan antara debit dan waktu tinggal terhadap efisiensi Biofilter Anaerob Aerob Media Bata Styrofoam Sistem Aliran Ke Atas dapat dilihat pada gambar 5 :

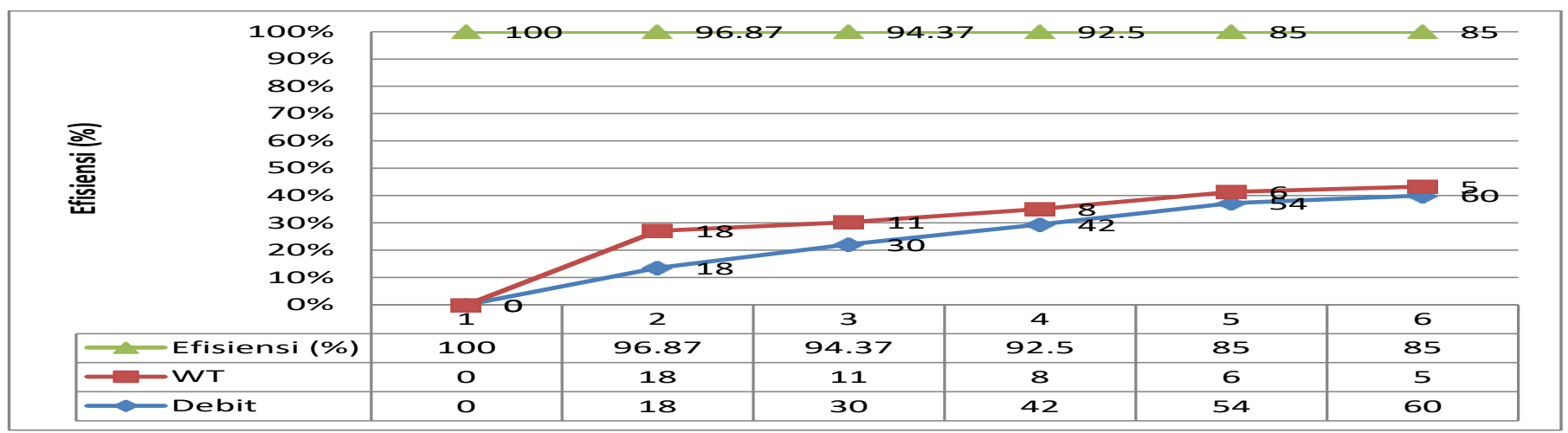

Gambar 5. Hubungan Debit dan Waktu Tinggal terhadap Efisiensi Biofilter Anearob Aerob

Berdasarkan tabel 3 menunjukkan bahwa ada perbedaan jumlah coliform sebelum dan sesudah pengolahan dengan biofilter anaerob aerob media bata styrofom sistem aliran ke atas. Untuk mengetahui hubungan antara debit dan waktu tinggal terhadap perbedaan coliform sebelum dan sesudah pengolahan dengan biofilter anaerob aerob media bata styrofom sistem aliran ke atas dapat dilihat pada gambar 6 dibawah ini : 


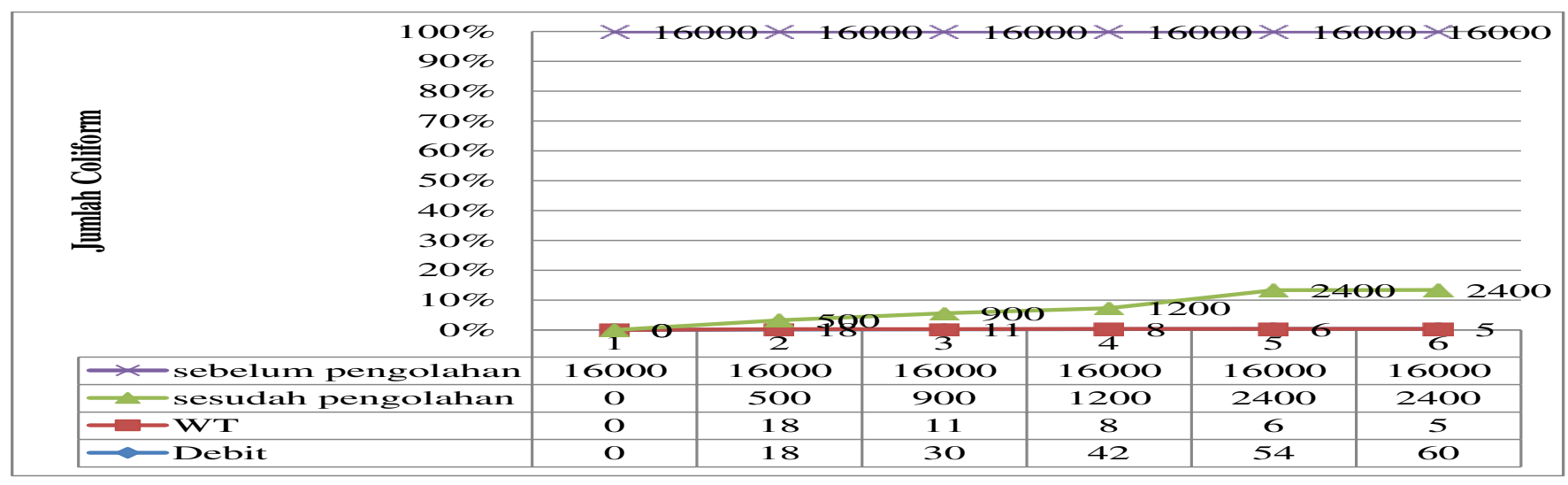

Gambar 6. Hubungan Debit dan Waktu Tinggal terhadap penurunan coliform sebelum dan sesudah pengolahan.

Penurunan coliform air limbah rumah sakit disebabkan oleh pengendapan bakteri coliform bersama partikel zat padat organik, tersuspensi, tidak stabil dan bersifat relatif besar secara grafitasi kedasar bak karena lambatnya aliran dan lamanya waktu tinggal, adanya kematian bakteri karena dimakan oleh mikroorganisme lain atau kalah berkompetensi dalam air limbah dan kekurangan nutrisi (Said, 2008)
Pada biofilter anaerob aerob media bata bakteri yang ada akan tertahan oleh media filter dan langsung dimakan oleh bakteri yang melapisi media tersebut sehingga mati. Dengan kematian tersebut jumlah bakteri coliform dalam air limbah berkurang. Untuk mengetahui apakah terdapat perbedaan yang signifikan kemampuan biofilter anaerob aerob media bata styrofoam sebelum dan sesudah pengolahan dilakukan uji statistik seperti pada tabel berikut :

Tabel 6. Hasil Uji Statistik Pengaruh Perbedaan Debit dan Waktu Tinggal terhadap Efisiensi Biofilter Anaerob Aerob

\begin{tabular}{|c|c|c|c|c|}
\hline No & Tes & $\begin{array}{c}\text { Jenis } \\
\text { Uji }\end{array}$ & Signifikansi & Kesimpulan \\
\hline 1 & Efektifitas Biofilter & T-Test & O,OOO & Signifikan \\
\hline 2 & $\begin{array}{l}\text { Hubungan Debit dengan } \\
\text { Efektifitas Biofilter }\end{array}$ & Regresi & 0,004 & Signifikan \\
\hline 3 & $\begin{array}{l}\text { Hubungan Waktu Tinggal dengan } \\
\text { Efektifitas Biofilter }\end{array}$ & Regresi & 0,024 & Signifikan \\
\hline
\end{tabular}

Berdasarkan tabel 6 bahwa dengan menggunakan uji T-tes menunjukan bahwa ada perbedaan penurunan MPN-Coliform sebelum dan sesudah pengolahan. Selanjutnya untuk mengetahui hubungan antara debit alir dengan penurunan MPN Coliform dilanjutkan dengan uji regresi. Dari hasil uji regresi diketahui korelasi debit (X1) dengan penurunan MPN Coliform $(\mathrm{Y}), \mathrm{r}=0,965$ artinya terdapat hubungan positif antara X1 dan Y dimana semakin lambat debit diikuti penurunan MPN-Coliform dengan nilai signifikansi $<\alpha(0,004<0,05)$ yang berarti hubungan antara X1 dan Y signifikan. Hubungan antara variabel waktu tinggal (X2) dengan penurunan MPN-Coliform (Y), $r=-0,882$ dengan nilai signifikansi $<\alpha(0,024<0,05)$ artinya hubungan tersebut signifikan. Nilai koefisien korelasi $\mathrm{R}=0,977$ artinya besarnya hubungan antara debit (X1) dan waktu tinggal
(X2) terhadap penurunan MPN Coliform sebesar $97,7 \%$, sedangkan koefisien determinasi R2 = 0,955 yang berarti besarnya hubungan antara variabel debit (X1), waktu tinggal (X2) dan penurunan MPN Coliform 95,5\% ditentukan oleh variabel X1 dan X2 dan sisanya dipengaruhi oleh variabel lain.

Faktor - faktor lain yang turut mempengaruhi pengolahan Biofilter Anaerob Aerob Media Bata Styrofoam Sistem Aliran Ke Atas dalam menurunkan kadar BOD, COD dan Coliform antara lain :

1. Suhu

Suhu memberi pengaruh terhadap kebanyakan reaksi biokimia. Aktivitas mikroorganisme akan meningkat pada suhu $60 \mathrm{oC}$. Kondisi suhu sebelum dan sesudah pengolahan seperti pada gambar 7 berikut : 


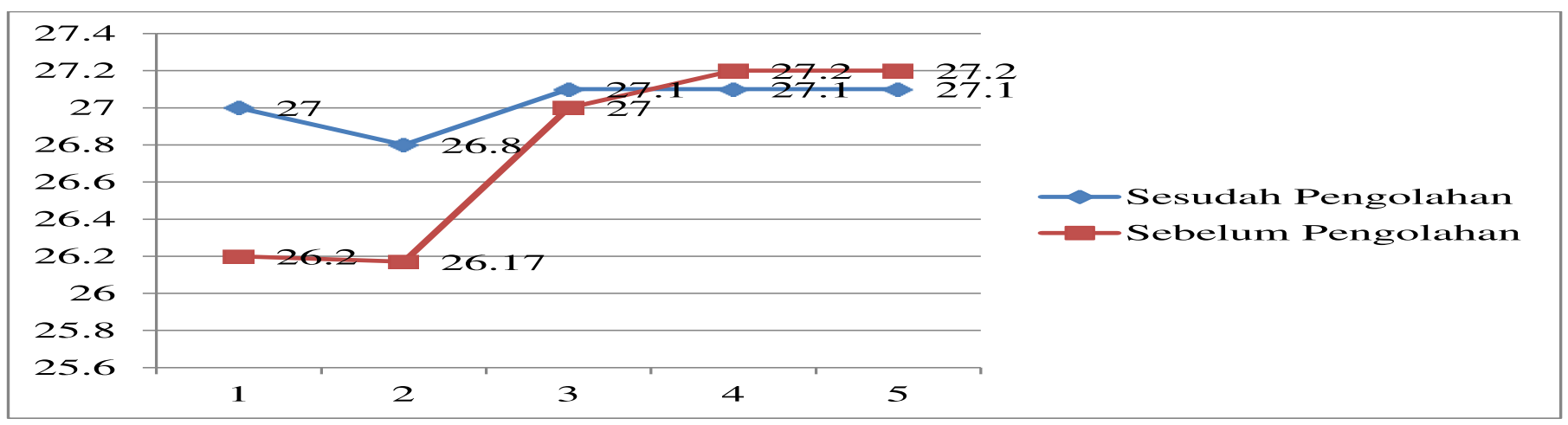

Gambar 7. Kondisi Suhu Sebelum dan Sesudah Pengolahan dengan Biofilter Anaerob Aerob Media Bata Styrofoam Sistem Aliran Ke Atas

Berdasarkan gambar 7 dapat dijelaskan bahwa suhu air limbah pada biofilter anaerob aerob media bata styrofoam sebelum pengolahan senantiasa menunjukan angka berkisar antara $26,2 \mathrm{oC}-27,1 \mathrm{oC}$ dan sesudah pengolahan berkisar antara $26,8 \mathrm{oC}-27,2 \mathrm{oC}$ Suhu yang tinggi akan merusak proses dengan mencegah aktivitas enzim dalam sel. Peningkatan suhu dapat menyebabkan penurunan efisiensi pengolahan.

2. $\mathrm{pH}$

Untuk mengetahui perubahan $\mathrm{pH}$, dilakukan pengukuran $\mathrm{pH}$ dengan menggunakan $\mathrm{pH}$ meter pada biofilter sebelum dan sesudah pengolahan yang menunjukan angka stabil seperti pada ggambar 8 dibawah ini :

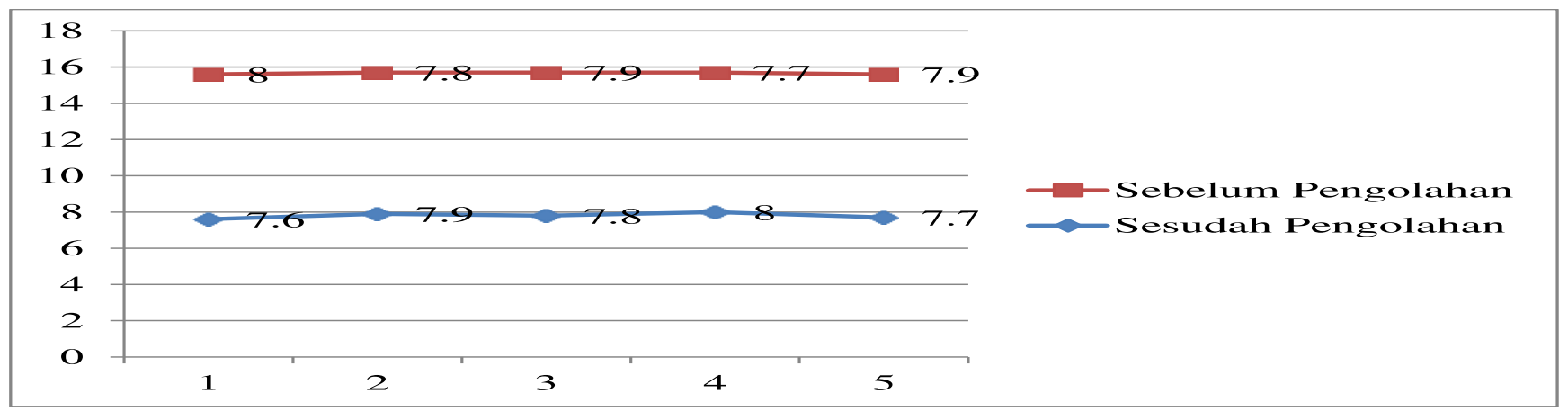

Gambar 8. Nilai pH Sebelum dan Sesudah Pengolahan dengan Biofilter Anaerob Aerob Media Bata Styrofoam Sistem Aliran Ke Atas.

Hasil penelitian menunjukan bahwa nilai $\mathrm{pH}$ tidak pernah mengalami penurunan $\mathrm{pH}$ yang signifikan baik sebelum maupun sesudah pengolahan dengan kisaran sebelum pengolahan antara 7,7 - 8 dan sesudah pengolahan 7,6-8. Ada beberapa bakteri yang dapat hidup dengan $\mathrm{pH}$ diatas 9,5 dan dibawah 4,0. Secara umum $\mathrm{pH}$ optimum bagi pertumbuhan mikroorganisme adalah sekitar $6,5-7,5$.
Nilai $\mathrm{pH}$ yang terlalu tinggi akan menghambat aktivitas mikroorganisme sedangkan nilai $\mathrm{pH}$ dibawah 6,5 akan mengakibatkan pertumbuhan jamur dan terjadi persaingan dengan bakteri dalam metabolisme materi organik.

Jika dihitung kebutuhan oksigen yang seharusnya terdapat dalam biofilter aerob adalah sebagai berikut : 
Diketahui :

Biofilter Anaerob :

$\begin{array}{ll}\text { Volume biofilter } & =0,096 \mathrm{~m}^{3} \times 2 \text { bak }=0,192 \mathrm{~m}^{3} \\ \text { Volume }_{\text {media }} & =50 \% \text { volume reaktor (Said, 2008) } \\ & =0.048 \mathrm{~m}^{3} \\ \text { BOD }_{\text {Inf }} & =179,13 \mathrm{mg} / \mathrm{l} \\ \text { Efisiensi } & =50 \%(\text { Said, } 2008) \\ \text { BOD }_{\text {Inf }} & =179 \mathrm{mg} / \mathrm{l}-(0,5 \times 179 \mathrm{mg} / \mathrm{l}) \\ \text { BOD }_{\text {Eff }} & =89,565 \mathrm{mg} / \mathrm{l}\end{array}$

Standar beban BOD yang digunakan $1,0 \mathrm{~kg} / \mathrm{m}^{3}$.hari (Said, 2008)

Maka beban $\mathrm{BOD}=\mathrm{V}_{\text {media }} \times 1,0 \mathrm{~kg} \mathrm{BOD} / \mathrm{m}^{3}$.hari

$$
=0,048 \mathrm{~m}^{3} \times 1,0 \mathrm{~kg}
$$

$\mathrm{BOD} / \mathrm{m}^{3} \cdot$ hari $\quad=0,048 \mathrm{~kg} \quad=48$ gram $/$ hari

Debit Air limbah yang masuk ke dalam biofilter :

$$
\begin{aligned}
& \mathrm{Q}=\frac{\text { Beban BOD dalam gram } / \text { hari }}{\text { BOD masuk biofilter }} \\
& \mathrm{Q}=\frac{48 \text { gram } / \mathrm{hari}}{179,13 \mathrm{gram} / \mathrm{m}^{3}} \\
& \mathrm{Q}=0,2679 \mathrm{~m}^{3} / \mathrm{hari}
\end{aligned}
$$

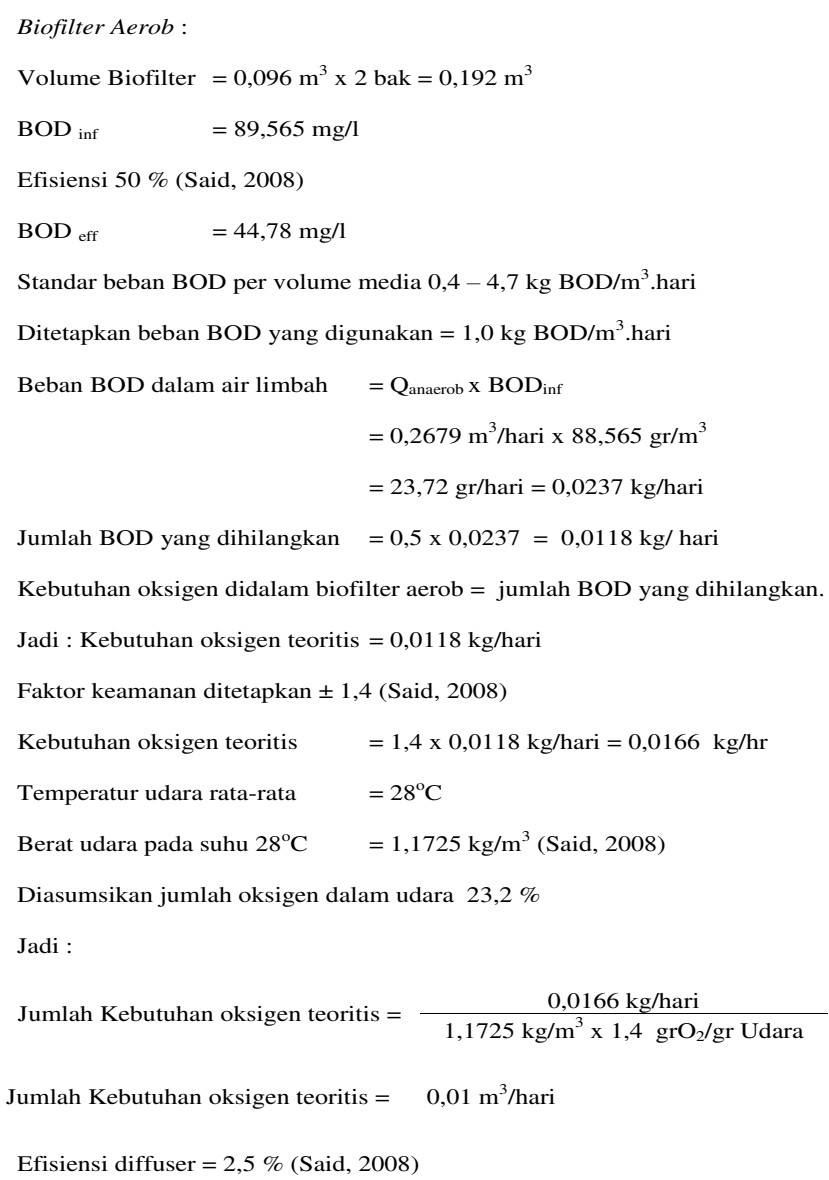

Berdasarkan perhitungan tersebut diketahui bahwa kebutuhan udara aktual sebanyak 0,4 $\mathrm{m} 3$ hari sedangkan dalam penelitian ini aerator yang digunakan adalah air pump dengan debit udara yang dikeluarkan sebesar 20 1/menit, dengan demikian debit udara yang masuk kedalam biofilter aerob sudah mencukupi kebutuhan oksigen untuk menguraikan ikatan senyawa air limbah rumah sakit.

\section{Hasil Konversi}

Diketahui

Jumlah Bed $\quad: 250$ bed
Kebutuhan air bersih $: 500$ l/bed

$$
\begin{array}{ll} 
& : 500 \mathrm{~L} \times 250 \text { bed }=125.000 \text { liter }=125 \mathrm{~m}^{3} \\
\text { Volume Limbah } \quad: 80 \% \text { Kebutuhan air bersih } \\
& : 80 / 100 \times 125 \mathrm{~m}^{3}=100 \mathrm{~m}^{3} / \text { hari }=4,2 \mathrm{~m}^{3} / \mathrm{jam}=70 \mathrm{l} / \mathrm{menit}
\end{array}
$$

a. Bak Pemisah lemak

\begin{tabular}{|c|c|}
\hline Kapasitas & $=100 \mathrm{~m}^{3} /$ hari $=4,2 \mathrm{~m}^{3} / \mathrm{jam}=70$ liter $/$ menit \\
\hline Waktu tinggal & $=30$ menit $=30$ menit $\times 70$ liter $=2100$ liter \\
\hline \multicolumn{2}{|l|}{ Dimensi Bak : } \\
\hline Panjang & $=2,0 \mathrm{~m}$ \\
\hline Lebar & $=1,0 \mathrm{~m}$ \\
\hline Tinggi & $=1,2 \mathrm{~m}$ \\
\hline Volume ruang bebas & $=0,3 \mathrm{~m}$ \\
\hline Volume efektif & $=2,4 \mathrm{~m}$ \\
\hline \multicolumn{2}{|l|}{ Bak Sedimentasi awal } \\
\hline BODinf & $=358,26 \mathrm{mg} / \mathrm{l}$ \\
\hline Efisiensi & $=50 \%$ \\
\hline BODeff & $=179.13 \mathrm{mg} / \mathrm{l}$ \\
\hline Waktu tinggal & $=4 \mathrm{jam}=4 / 24 \times 100 \mathrm{~m}^{3}=16,7 \mathrm{~m}^{3}$ \\
\hline \multicolumn{2}{|l|}{ Dimensi Bak } \\
\hline Panjang & $=3,5 \mathrm{~m}$ \\
\hline Lebar & $=3,5 \mathrm{~m}$ \\
\hline Tinggi & $=1,4 \mathrm{~m}$ \\
\hline Volume ruang bebas & $=0,45 \mathrm{~m}$ \\
\hline Volume efektif & $=17.15 \mathrm{~m}$ \\
\hline
\end{tabular}

Bak pemisah lemak atau grease removal yang direncanakan adalah tipe gravitasi sederhana. Bak terdiri dari dua buah ruangan yang dilengkap dengan bar screen pada bagian inletnya.

Kriteria perencanaan : 
JKL Volume 9 No. 1 April 2019

a. Bak Equalisasi :

\begin{tabular}{|c|c|}
\hline Kapasitas Pengolahan & $=100 \mathrm{~m}^{3} / \mathrm{hari}=4,2 \mathrm{~m}^{3} / \mathrm{jam}=70$ liter $/$ menit \\
\hline Waktu tinggal di bak equalisasi & $=8 \mathrm{jam}$ \\
\hline Volume Bak Equalisasi & $=8 / 24 \times 100 \mathrm{~m}^{3} /$ hari $=33,3 \mathrm{~m}^{3}$ \\
\hline \multicolumn{2}{|l|}{ Maka dimensi bak: } \\
\hline Panjang & $=4,0 \mathrm{~m}$ \\
\hline Lebar & $=4,0 \mathrm{~m}$ \\
\hline Tinggi & $=2,1 \mathrm{~m}$ \\
\hline Tinggi ruang bebas & $=0,3 \mathrm{~m}$ \\
\hline Volume efektif & $=33,6 \mathrm{~m}$ \\
\hline Bak Biofilter Anaerob : & \\
\hline Kapasitas Pengolahan & $=100 \mathrm{~m}^{3} / \mathrm{hari}=4,2 \mathrm{~m} 3 / \mathrm{jam}=70$ liter $/$ menit \\
\hline $\mathrm{BOD}_{\mathrm{inf}}$ & $=179,13 \mathrm{mg} / \mathrm{l}$ \\
\hline Efisiensi pengolahan & $=50 \%$ \\
\hline $\mathrm{BOD}_{\text {eff }}$ & $=89,565 \mathrm{mg} / 1$ \\
\hline
\end{tabular}

Waktu tinggal di bak biofilter anaerob aerob $=9$ jam

Volume Bak Biofilter anaerob

$=9 / 24 \times 100 \mathrm{~m}^{3}=37,5 \mathrm{~m}^{3}$

Volume Bak Biofilter Aerob $=9 / 24 \times 100 \mathrm{~m}^{3}=37,5 \mathrm{~m}^{3}$

Maka Dimensi masing-masing bak :

$\begin{array}{ll}\text { Panjang } & =4,0 \mathrm{~m} \\ \text { Lebar } & =4,0 \mathrm{~m} \\ \text { Tinggi } & =2,4 \mathrm{~m} \\ \text { Tinggi ruang bebas } & =0,9 \mathrm{~m}\end{array}$

Untuk pengolahan air dengan proses biofilter standar beban BOD per volume media $0,4-4,7 \mathrm{~kg} \mathrm{BOD} / \mathrm{m} 3$.hari.

Ditetapkan beban BOD yang digunakan $=1,0$ $\mathrm{BOD} / \mathrm{m} 3$.hari

Beban BOD di dalam air limbah $\quad=100 \mathrm{~m} 3$ x $179,13 \mathrm{gr} / \mathrm{m} 3=17913 \mathrm{~g} / \mathrm{hari}=17,9 \mathrm{~kg} / \mathrm{hari}$
Diadon, dkk. Efektifitas Biofilter Anaerob Aerob,

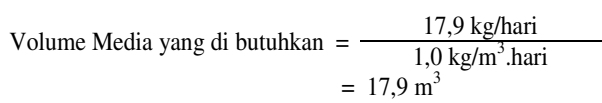

Kebutuhan Oksigen :

$\begin{array}{ll}\text { Kapasitas pengolahan } & =100 \mathrm{~m}^{3} \\ \mathrm{BOD}_{\text {inf }} & =89,565 \mathrm{mg} / \mathrm{l} \\ \text { Efisiensi } & =50 \% \\ \mathrm{BOD}_{\text {eff }} & =44,8 \mathrm{mg} / \mathrm{l}\end{array}$

Untuk pengolahan air dengan proses biofilter standar beban BOD per volume media $0,4-4,7 \mathrm{~kg} \mathrm{BOD} / \mathrm{m}^{3}$.hari.

Ditetapkan beban BOD yang digunakan $=1,0 \mathrm{BOD} / \mathrm{m}^{3}$.hari

Beban BOD di dalam air limbah $=100 \mathrm{~m}^{3} \times 89,565 \mathrm{gr} / \mathrm{m}^{3}=8956,5 \mathrm{~g} / \mathrm{hari}$

$=9 \mathrm{~kg} / \mathrm{hari}$

Jumlah BOD yang dihilangkan $=0,5 \times 9 \mathrm{~kg} / \mathrm{hari}$

$$
=4,5 \mathrm{~kg} / \mathrm{hari}
$$

Kebutuhan oksigen di dalam reaktor $=$ jumlah BOD yang dihilangkan

$$
=4,5 \mathrm{~kg} / \mathrm{hari}
$$

Faktor keamanan yang ditetapkan $= \pm 1,4$ volume reaktor

$$
\begin{array}{ll}
\text { Kebutuhan oksigen teoritis } & =1,4 \times 4,5 \mathrm{~kg} / \mathrm{hari}=6,3 \mathrm{~kg} / \mathrm{hari} \\
\text { Temperatur udara rata-rata } & =28^{\circ} \mathrm{C} \\
\text { Berat udara pada suhu } 28^{\circ} \mathrm{C} & =1,1725 \mathrm{~kg} / \mathrm{m}^{3}
\end{array}
$$

Diasumsikan jumlah oksigen didalam udara adalah 23,3\% Jadi :

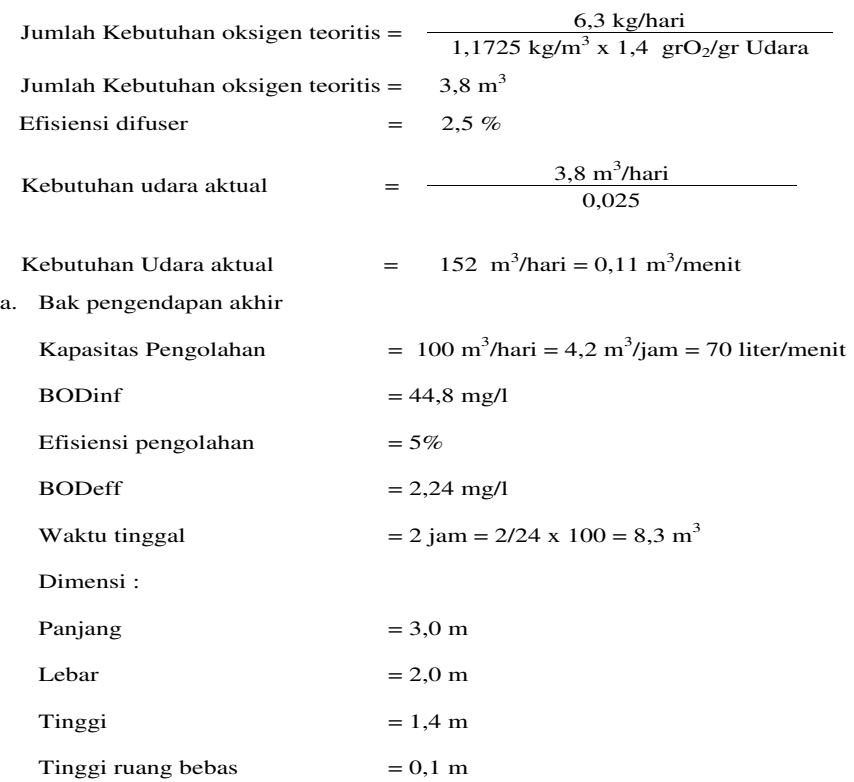




\begin{tabular}{|c|c|}
\hline \multicolumn{2}{|c|}{ Faktor keamanan yang ditetapkan $= \pm 1,4$ volume reaktor } \\
\hline Kebutuhan oksigen teoritis & $=1,4 \times 4,5 \mathrm{~kg} / \mathrm{hari}=6,3 \mathrm{~kg} / \mathrm{hari}$ \\
\hline Temperatur udara rata-rata & $=28^{\circ} \mathrm{C}$ \\
\hline Berat udara pada suhu $28^{\circ} \mathrm{C}$ & $=1,1725 \mathrm{~kg} / \mathrm{m}^{3}$ \\
\hline \multicolumn{2}{|c|}{ Diasumsikan jumlah oksigen didalam udara adalah 23,3\% } \\
\hline \multicolumn{2}{|l|}{ Jadi : } \\
\hline \multirow{2}{*}{ Jumlah Kebutuhan oksigen teoritis = } & $6,3 \mathrm{~kg} / \mathrm{hari}$ \\
\hline & $1,1725 \mathrm{~kg} / \mathrm{m}^{3} \times 1,4 \mathrm{grO}_{2} / \mathrm{gr}$ Udara \\
\hline Jumlah Kebutuhan oksigen teoritis $=$ & $\mathrm{s}=3,8 \mathrm{~m}^{3}$ \\
\hline Efisiensi difuser & $=2,5 \%$ \\
\hline \multirow{2}{*}{ Kebutuhan udara aktual } & $3,8 \mathrm{~m}^{3} /$ hari \\
\hline & 0,025 \\
\hline Kebutuhan Udara aktual & $=152 \mathrm{~m}^{3} /$ hari $=0,11 \mathrm{~m}^{3} / \mathrm{menit}$ \\
\hline \multicolumn{2}{|l|}{ Bak pengendapan akhir } \\
\hline Kapasitas Pengolahan & $=100 \mathrm{~m}^{3} / \mathrm{hari}=4,2 \mathrm{~m}^{3} / \mathrm{jam}=70$ liter $/ \mathrm{meni}$ \\
\hline BODinf & $=44,8 \mathrm{mg} / \mathrm{l}$ \\
\hline Efisiensi pengolahan & $=5 \%$ \\
\hline BODeff & $=2,24 \mathrm{mg} / \mathrm{l}$ \\
\hline Waktu tinggal & $=2 \mathrm{jam}=2 / 24 \times 100=8,3 \mathrm{~m}^{3}$ \\
\hline \multicolumn{2}{|l|}{ Dimensi : } \\
\hline Panjang & $=3,0 \mathrm{~m}$ \\
\hline Lebar & $=2,0 \mathrm{~m}$ \\
\hline Tinggi & $=1,4 \mathrm{~m}$ \\
\hline Tinggi ruang bebas & $=0,1 \mathrm{~m}$ \\
\hline
\end{tabular}

\section{Kesimpulan}

Berdasarkan hasil penelitian dan pembahasan, dapat disimpulkan bahwa :

1. Biofilter Anaerob Aerob Media Bata Styrofoam Sistem Aliran Ke Atas efektif menurunkan kadar BOD, COD dan Coliform air limbah rumah sakit.

2. Ada hubungan antara debit (1/jam) dan waktu tinggal (jam) terhadap efektivitas Biofilter Anaerob Aerob Media Bata Styrofoam Sistem Aliran Ke Atas dalam menurunkan kadar BOD, COD.

3. Coliform air limbah rumah sakit.

Ada hubungan antara suhu dan $\mathrm{pH}$ terhadap efektifitas Biofilter Anaerob Aerob Media Bata Styrofoam Sistem Aliran Ke Atas dalam menurunkan kadar BOD, COD dan Coliform air limbah rumah sakit.

4. Kebutuhan oksigen melebihi kapasitas volume air limbah rumah sakit

\section{Saran}

1. Agar dapat diketahui Biofilter Anaerob Aerob Media Bata Styrofoam Sistem Aliran Ke Atas dalam mengolah air limbah rumah sakit dengan lebih baik, maka perlu ada penelitian lanjutan dengan parameter yang lain seperti TSS, Phospat dan nitrit.

2. Dalam penerapan dilapangan hendaknya kebutuhan oksigen dihitung dengan tepat kemudian dikonfirmasikan dengan kapasitas pompa yang akan digunakan untuk aerasi agar proses dekomposisi oleh bakteri lebih optimal.

\section{Daftar Pustaka}

Keputusan Menteri Lingkungan Hidup RI No. 58 tahun 1995 tentang Baku Mutu Air Limbah Rumah Sakit. Jakarta.

Kristanto Ph., 2002., Ekologi Industri., Andi., Yogyakarta

Notoatmodjo, 2010. Metodologi Penelitian Kesehatan, Jakarta : Rineke Cipta

Said, Nusa Idaman, 2008., Teknologi Pengolahan Air Minum Teori dan Pengalaman Praktis., Pusat Teknologi Lingkungan. Jakarta.

Sugiyono, 2011., Metode Penelitian Kombinasi (Mixed Method)., Penerbit Alfabeta. Bandung.

Sunu., 2001., Melindungi Lingkungan dengan Menerapkan ISO 14001., Gramedia Widasarana Indonesia., Jakarta.

Timpua T.K., (2005)., Efektivitas Trickling Filter Up Flow dalam Pengolahan Limbah Cair Rumah Sakit. Tesis., Universitas Sam Ratulangi. Manado.

Undang-Undang No 44 : 2009 tentang Rumah Sakit. Jakarta 